\title{
Sciendo
}

\section{Comparison between thrombophilic gene polymorphisms among high risk patients}

\author{
MARIYA LEVKOVA ${ }^{1,2}$, MARI HACHMERIYAN $^{1,2}$, MILENA STOYANOVA $^{1,2}$, \\ VALENTINA MITEVA $^{1,2}$, LYUDMILA ANGELOVA $^{1,2}$ \\ ${ }^{1}$ Department of Medical Genetics, Medical University Varna, 55 Marin Drinov Str, Varna, 9000, Bulgaria \\ ${ }^{2}$ Laboratory of Medical Genetics, St. Marina Hospital, 1 Hristo Smirnenski Blv, Varna, 9000, Bulgaria
}

\begin{abstract}
Introduction. The purpose of this study was to compare the role of the thrombophilic variants among two groups of high risk patients with vascular disorders and recurrent pregnancy loss.

Methods. 200 patients, including 76 with thrombotic accidents and 124 with two or more idiopathic recurrent miscarriage during the first trimester, were tested for the presence of Factor $\mathrm{V}$ (F V) Leiden G1691A, Factor II (F II) G20210A, plasminogen activator inhibitor (PAI) 4G/5G, and methylenetetrahydrofolate reductase (MTHFR) C677T polymorphisms using Real time polymerase chain reaction (RT - PCR) in the Laboratory of Medical Genetics, Varna, Bulgaria between June 2016 and May 2019. Frequencies of thrombophilic gene polymorphisms were compared among the two populations and to the expected genotype frequencies.

Results. Individuals with a history of vascular disorders had a significantly higher frequency of F V Leiden variant compared to women with recurrent miscariage. There was no statistical difference between the analyzed patients for the other three thrombophilic polymorphisms. The allelic frequencies and the expected genotype frequencies of the F V, F II and MTHFR polymorphisms were calculated according to Hardy-Weinberg equilibrium. The percentages of the homozygotes for F V and F II were higher than expected in the two groups of patients. For the MTHFR there was no difference.

Conclusion. F V Leiden remains the strongest risk factor for vascular disorders and recurrent pregnancy loss. Screening for this variant should be recommended to patients with thrombotic accidents and women with repeated miscarriage. The role of F II, PAI and MTHFR remains controversial.
\end{abstract}

Key words: thrombophilia, Factor V, vascular diseases, miscarriage, genetic polymorphism.

\section{INTRODUCTION}

Thrombophilia is a blood clotting disorder, which can be inherited or acquired. It could be suspected in cases of venous thromboembolism, ischemic stroke, especially in cases of early onset, recurrent thrombotic episodes, family history, etc [1]. It has been also investigated as a risk factor for recurrent miscarriage [2].

Inherited thrombophilia is responsible for more than $40 \%$ of idiopathic thromboembolic events [2]. Possible causes of inherited thrombophilia are antithrombin III, protein $\mathrm{C}$, protein $\mathrm{S}$ deficiency or a mutation in factor $\mathrm{V}$ Leiden $(\mathrm{F} \mathrm{V})$, factor II prothrombin (F II), plasminogen activator inhibitor (PAI) and methylenetetrahydrofolate reductase (MTHFR) genes [3].

F V Leiden is considered a major risk factor for predisposition to thrombophilia. A substitution of arginine with glutamine at position 506 in the factor $\mathrm{V}$ causes resistance to activated protein $\mathrm{C}$ and it is found in around 5\% of Caucasians $[4,5]$.
Mutation, caused by replacement of guanosine with adenosine in the gene, coding F II, is associated with elevated levels of prothrombin in the blood [6] and has a frequency distribution of around $2.3 \%$ in Caucasians from European descent [7]. The 4G/4G polymorphism of PAI correlates with an increased risk for venous thrombosis due to higher PAI-1 plasma levels and defected fibronolysis of the clot [8]. MTHFR is an enzyme, which has a crucial role in the metabolism of homocysteine by converting it into methionine [9]. However, the C677T polymorhism in the gene, coding MTHFR, causes an impaired function of the enzyme, higher levels of homocysteine and a potentially increased risk for thrombosis [10].

These genetic polymorphisms could be associated with microthrombosis in the placenta or trophoblast, deep venous thrombosis and stroke. Despite the fact that the results from different studies are controversial, the genetic tests for inherited thrombophilia are requested by clinicians in cases of deep venous thrombosis and unexplained recurrent miscarriages. 
The aim of this study is to analyze the frequency distribution of these mutations in patients with vascular disorders (VDs) and recurrent pregnancy loss (RPL), and to evaluate the role of studied polymorphisms as a risk factor for vascular disorders and infertility.

\section{MATERIALS AND METHODS}

A total of 200 patients divided into two groups were analyzed between June 2016 and May 2019 in the Laboratory of Medical Genetics in Varna, Bulgaria. Informed consent was obtained from all participants in the study prior to the analysis. First group consisted of 39 female and 38 male patients with vascular disorders such as deep venous thrombosis, pulmonary embolism, stroke, etc. The second group included 124 women with primary infertility, two or more recurrent miscarriages between $8^{\text {th }}$ and $12^{\text {th }}$ gestational week and without any anatomical, infectious, or endocrine diseases.

Genomic DNA samples from the individuals were extracted from peripheral blood by a salting out procedure and genotyped for F V Leiden (G1691A),
F II (G20210A), PAI 4G/5G, and MTHFR (C677T) polymorphisms using Real time polymerase chain reaction (RT - PCR) (QuantStudio Dx, Applied Biosystems, USA) according to the manufacturer protocol (Generi Biotech).

Differences between the two groups were analyzed by Graphpad Prism software (version 8) using Chi-square test. The chi-square calculations are only valid when all expected values are greater than 1.0 and at least $20 \%$ of the expected values are greater than 5. A two-tailed p-value was used and a difference was considered significant at a $p$ value $<0.05$. The allelic frequencies for F V, F II and MTHFR polymorphisms were extracted from gnomAD database and used to determine the genotype frequencies by applying the HardyWeinberg equation.

\section{RESULTS}

The median age of the participants with VDs was 38.95 (standard deviation, $\mathrm{SD}=17.55$ ) and of the women with recurrent miscarriges was 32.62 years $(\mathrm{SD}=5.83)$.

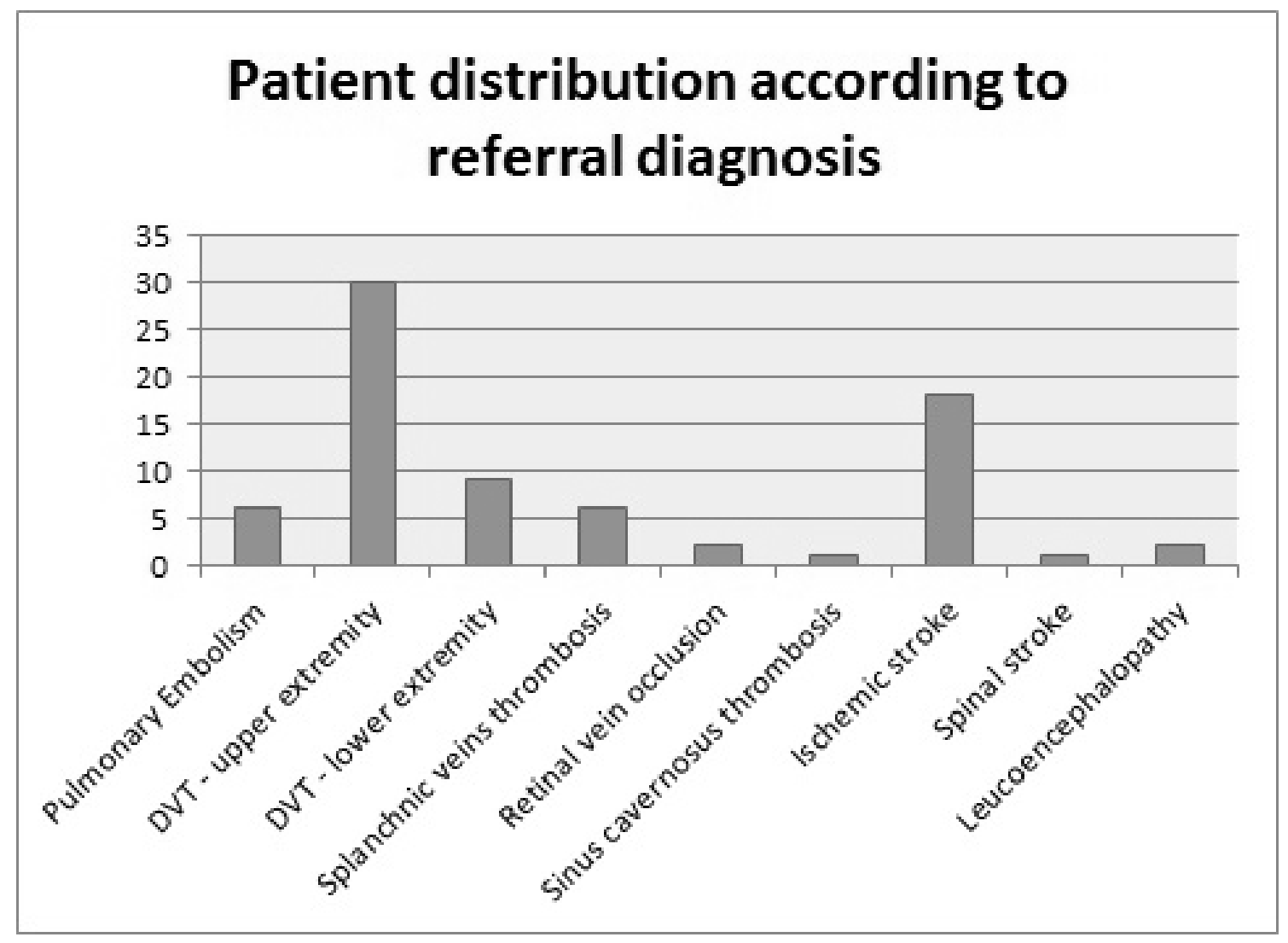

Figure 1. Patient distribution of referral diagnosis of the included patients with vascular disorders. DVT - deep vein thrombosis. 
The VDs group consisted of 39 (50.6\%) female and 38 (49.4\%) male patients. Main indications for testing were deep vein thrombosis of upper or lower extremities - 39 (51.3\%), and ischemic stroke $18(23.7 \%)$. The rest $19(25 \%)$ referral diagnoses included pulmonary embolism, thrombosis of the splanchnic veins or sinus cavernosus, retinal vein occlusion, spinal stroke and leucoencephalopathy.

From all investigated women with RPL 83 $(67.0 \%)$ had two miscarriages, the rest $41(33.0 \%)$ had three or more.

There was one $(1.3 \%)$ homozygote for the mutant allele for F V Leiden (G1691A) and fifteen (19.7\%) heterozogytes in VDs group. In the RPL group there were eleven (8.9\%) heterozygotes and one $(0.8 \%)$ homozygote. There was a statistically significant difference (Chi-square, df 4.993, 1; $\mathrm{p}=0.0254$ ) between the two groups for the F V polymorphism.

For F II there were $6(7.9 \%)$ heterozygotes from the VDs and and $3(2.4 \%)$ from the RPL group. No homozygotes for the mutant for F II (G20210A) allele were found in both groups. There was no statistical difference between the analyzed patients (Chi-square, df 3.287, 1, p = 0.0698).

The results for the PAI polymorphism showed $38(53.5 \%)$ 4G/5G heterozygotes and 14 (19.7\%)
$4 \mathrm{G} / 4 \mathrm{G}$ homozygotes for the mutant allele from the VDs group. For the RPL group their number was $67(54.5 \%)$ and $32(26.0 \%)$ respectively. The data from the chi-square tests did not differ statistically (Chi-square, df 1.828, 2; p = 0.4010).

$32(47.0 \%)$ patients from the VDS group were proved to be heterozygote carriers for the MTHFR (C677T) polymorphism and $7(10.6 \%)$ - homozygotes for the mutant MTHFR (C677T) allele. For the RPL group the distrubtion was 48 (39.3\%) and 15 $(12.3 \%)$ respectively. The data from the chi-square tests did not differ statistically (Chi-square test, $\mathrm{df}$ $1.114,2 ; \mathrm{p}=0.5729)($ Table 1).

In the VDs group there were $13(18.3 \%)$ participants, who were isolated homozygous carriers of the PAI mutant allele and from the RPL group there were $28(22.8 \%)$ women. The number of homozygotes only for the mutated MTHFR alleles in the VDs group was $6(7.9 \%)$ and in the other group - $11(9.0 \%)$.

The allelic frequencies and the expected genotype frequencies of the three polymorphisms were calculated according to Hardy-Weinberg equilibrium (Table 2). The percentages of the homozygotes for F V and F II were higher than expected in the two groups of patients. For the MTHFR there was no difference.

Table 1

Frequency distribution of thrombophilic variants among the studied population and results from statistical analysis

\begin{tabular}{|c|c|c|c|c|}
\hline Genotype & VDs ${ }^{\mathrm{a}}$ Patients & RPL ${ }^{b}$ Patients & $\begin{array}{c}\text { Statistical } \\
\text { analysis }\end{array}$ & $p$ value \\
\hline F V Leiden 1691A & Total: 76 & Total: 124 & & \\
\hline $\begin{array}{l}\mathrm{WT}^{\mathrm{h}} \\
\mathrm{Het}^{\mathrm{i}} \\
\mathrm{Mut}^{\mathrm{j}}\end{array}$ & $\begin{array}{l}\mathrm{N}^{\mathrm{k}}=60(79.0 \%) \\
\mathrm{N}^{\mathrm{k}}=15(19.7 \%) \\
\mathrm{N}^{\mathrm{k}}=1(1.3 \%)\end{array}$ & $\begin{array}{l}\mathrm{N}^{\mathrm{k}}=112(90.3 \%) \\
\mathrm{N}^{\mathrm{k}}=11(8.9 \%) \\
\mathrm{N}^{\mathrm{k}}=1(0.8 \%)\end{array}$ & $\begin{array}{l}\text { Chi-square, } \mathrm{df}^{\mathrm{g}} \\
4.993,1\end{array}$ & $\begin{array}{l}\mathrm{p}=0.0254 \\
\text { significant }\end{array}$ \\
\hline F II ${ }^{\mathrm{d}} \mathrm{G} 20210 \mathrm{~A}$ & Total: 76 & Total: 124 & & \\
\hline $\begin{array}{l}\text { WT }^{\mathrm{h}} \\
\mathrm{Het}^{\mathrm{i}} \\
\mathrm{Mut}^{\mathrm{j}}\end{array}$ & $\begin{array}{l}\mathrm{N}^{\mathrm{k}}=70(92.1 \%) \\
\mathrm{N}^{\mathrm{k}}=6(7.9 \%) \\
\mathrm{N}^{\mathrm{k}}=0(0 \%)\end{array}$ & $\begin{array}{l}\mathrm{N}^{\mathrm{k}}=121(97.6 \%) \\
\mathrm{N}^{\mathrm{k}}=3(2.4 \%) \\
\mathrm{N}^{\mathrm{k}}=0(0 \%)\end{array}$ & $\begin{array}{l}\text { Chi-square, } \mathrm{df}^{\mathrm{g}} \\
3.287,1\end{array}$ & $\begin{array}{l}\mathrm{p}=0.0698 \\
\text { nonsignificant }\end{array}$ \\
\hline$\underline{\mathrm{PAI}^{\mathrm{e}} 4 \mathrm{G} / 5 \mathrm{G}}$ & Total: 71 & Total: 123 & & \\
\hline $\begin{array}{l}\mathrm{WT}^{\mathrm{h}} \\
\mathrm{Het}^{\mathrm{i}} \\
\mathrm{Mut}^{\mathrm{j}}\end{array}$ & $\begin{array}{l}\mathrm{N}^{\mathrm{k}}=19(26.8 \%) \\
\mathrm{N}^{\mathrm{k}}=38(53.5 \%) \\
\mathrm{N}^{\mathrm{k}}=14(19.7 \%)\end{array}$ & $\begin{array}{l}\mathrm{N}^{\mathrm{k}}=24(19.5 \%) \\
\mathrm{N}^{\mathrm{k}}=67(54.5 \%) \\
\mathrm{N}^{\mathrm{k}}=32(26.0 \%)\end{array}$ & $\begin{array}{l}\text { Chi-square, } \mathrm{df}^{\mathrm{g}} \\
1.828,2\end{array}$ & $\begin{array}{l}\mathrm{p}=0.4010 \\
\text { nonsignificant }\end{array}$ \\
\hline $\begin{array}{c}\text { MTHFR }^{\mathrm{f}} \text { C677T } \\
\text { WT }^{\mathrm{h}} \\
\mathrm{Het}^{\mathrm{i}}{ }^{\mathrm{j}} \\
\mathrm{Mut}^{\mathrm{j}}\end{array}$ & $\begin{aligned} \text { Total: } 66 \\
\\
\mathrm{~N}^{\mathrm{k}}=28(42.4 \%) \\
\mathrm{N}^{\mathrm{k}}=32(47.0 \%) \\
\mathrm{N}^{\mathrm{k}}=7(10.6 \%)\end{aligned}$ & $\begin{aligned} & \text { Total: } 122 \\
\mathrm{~N}^{\mathrm{k}} & =59(48.46 \%) \\
\mathrm{N}^{\mathrm{k}} & =48(39.3 \%) \\
\mathrm{N}^{\mathrm{k}} & =15(12.3 \%)\end{aligned}$ & $\begin{array}{l}\text { Chi-square test, } \\
\mathrm{df}^{\mathrm{g}} 1.114,2\end{array}$ & $\begin{array}{l}\mathrm{p}=0.5729 \\
\text { nonsignificant }\end{array}$ \\
\hline
\end{tabular}

${ }^{\mathrm{a}}$ Vascular diorders (VDs), ${ }^{\mathrm{b}}$ Recurrent pregnancy loss (RPL), ${ }^{\mathrm{c}}$ Factor V Leiden (F V), ${ }^{\mathrm{d}}$ Factor II (F II), ${ }^{\mathrm{e}}$ Plasminogen activator inhibitor (PAI), ${ }^{\mathrm{f}}$ Methylenetetrahydrofolate reductase (MTHFR), ${ }^{\mathrm{g}}$ difference (df), ${ }^{\mathrm{h}}$ Wild type (WT) allele, ${ }^{\mathrm{i}}$ Heterozygotes (Het), ${ }^{\mathrm{j}}$ Homozygotes for the mutant allele (Mut), ${ }^{\mathrm{k}}$ Number $(\mathrm{N})$. 
Table 2

Comparison between the expected and observed genotype frequencies of the studied thrombophilic variants

\begin{tabular}{|c|c|c|}
\hline Expected genotype frequencies & $\begin{array}{l}\text { Observed genotype frequencies - } \\
\text { VDs }^{\mathrm{a}} \text { group }\end{array}$ & $\begin{array}{l}\text { Observed genotype frequencies - } \\
\text { RPL }^{\mathbf{b}} \text { group }\end{array}$ \\
\hline F V $\mathrm{V}^{\mathrm{c}}$ Leiden: & Total: 76 & Total: 124 \\
\hline $\begin{array}{l}-92.1 \% \text { homozygotes wildtype allele } \\
-7.7 \% \text { heterozygotes } \\
-0.2 \% \text { homozygotes mutant allele }\end{array}$ & $\begin{array}{l}\mathrm{N}^{\mathrm{f}}=60(79.0 \%) \\
\mathrm{N}^{\mathrm{f}}=15(19.7 \%) \\
\mathrm{N}^{\mathrm{f}}=1(1.3 \%)\end{array}$ & $\begin{array}{l}\mathrm{N}^{\mathrm{f}}=112(90.3 \%) \\
\mathrm{N}^{\mathrm{f}}=11(8.9 \%) \\
\mathrm{N}^{\mathrm{f}}=1(0.8 \%)\end{array}$ \\
\hline$\underline{\mathrm{F} \mathrm{II}^{\mathrm{d}}:}$ & Total: 76 & Total: 124 \\
\hline $\begin{array}{l}-97.5 \% \text { homozygotes wild type allele } \\
-2.5 \% \text { heterozygotes } \\
-0.02 \% \text { homozygotes mutant allele }\end{array}$ & $\begin{array}{l}\mathrm{N}^{\mathrm{f}}=70(92.1 \%) \\
\mathrm{N}^{\mathrm{f}}=6(7.9 \%) \\
\mathrm{N}^{\mathrm{f}}=0(0 \%)\end{array}$ & $\begin{array}{l}\mathrm{N}^{\mathrm{f}}=121(97.6 \%) \\
\mathrm{N}^{\mathrm{f}}=3(2.4 \%) \\
\mathrm{N}^{\mathrm{f}}=0(0 \%)\end{array}$ \\
\hline$\underline{\text { MTHFR }^{\mathrm{e}}:}$ & Total: 66 & Total: 122 \\
\hline $\begin{array}{l}-41.8 \% \text { homozygotes wild type allele } \\
-45.7 \% \text { heterozygotes } \\
-12.5 \% \text { homozygotes mutant allele }\end{array}$ & $\begin{array}{l}\mathrm{N}^{\mathrm{f}}=28(42.4 \%) \\
\mathrm{N}^{\mathrm{f}}=32(47.0 \%) \\
\mathrm{N}^{\mathrm{f}}=7(10.6 \%)\end{array}$ & $\begin{array}{l}\mathrm{N}^{\mathrm{f}}=59(48.4 \%) \\
\mathrm{N}^{\mathrm{f}}=48(39.3 \%) \\
\mathrm{N}^{\mathrm{f}}=15(12.3 \%)\end{array}$ \\
\hline
\end{tabular}

${ }^{\mathrm{a}}$ Vascular disorders (VDs), ${ }^{\mathrm{b}}$ Recurrent pregnancy loss (RPL), ${ }^{\mathrm{c}}$ Factor V (F V) Leiden, ${ }^{\mathrm{d}}$ Factor II (F II), ${ }^{\mathrm{e}}$ Methylenetetrahydrofolate reductase (MTHFR), f Number (N).

\section{DISCUSSION}

Testing for thrombophilia in patients with vascular disorders is controversial and there are no clear guidelines. According to the American Society of Hematologists it should be avoided, if the patients have other risk factors such as surgery or trauma [11]. The patients in the VDs group had no other risk factors. Only one patient reported family history of VTE. However, if these are absent and if the patient is young, with family history of VTE, it is suggested to test for hereditary thrombophilia $[12,13]$. This recommendation is also supported by the fact that carrying at least one genetic defect increases about 4 times the thrombogenic risk compared to non-carriers [14]. Moreover, this genetic analysis could be used in patients with both hereditary thrombophilia and antiphospholipid syndrome since this combination increases siginificantly the risk for thrombotic accidents [15].

According to ESHRE guideline for RPL testing for hereditary thrombophilia is not suggested unless the women have other risk factors, such as family history of hereditary thrombophilia or previous venous thromboembolism (VTE) [16]. However, according to a research, conducted among 154 Bulgarian women with single embryonic loss and 100 healthy controls, it was concluded that F V Leiden had an impact on adverse pregnancy outcomes, especially in the second and third trimester [17]. F V could have a potential effect on the recurrent miscarriage according to other research groups $[18,19]$. Moreover, it is suggested as a risk factor for women, having primary infertility [20], which is also the case in our studied group.
In order to compare the role of $\mathrm{F} V$ Leiden among the two studied groups, we performed a chi-square test. The chi-square calculations are only valid when all expected values are greater than 1.0 and at least $20 \%$ of the expected values are greater than 5 . These conditions have not been met for the results for F V Leiden. That is why we excluded the homozygotes for the mutant allele because their number was equal. Since chi-square test calculates an approximate $\mathrm{p}$ value, we also applied the Fisher's exact test and there was a significant difference $(p=0.0309)$. After analyzing the frequncies of this $\mathrm{F} \mathrm{V}(\mathrm{G} 1691 \mathrm{~A})$ polymorphism among the studied groups, we concluded that this allele was more frequent among the group of patients with vaslucar disorders. These findings correlate with another research study, which concluded that the group with a history of deep vein thrombosis had higher percentages of all studied thrombophilic polymorphisms, compared to women with RPL and control patients [21]. According to the results from our study F V Leiden polymorphism could have a potential aggravating effect, especially on the risk of vascular disoders, since it is more common among the VDs group.

For F II, PAI and MTHFR polymorphisms we did not find any statistical difference betweeen the two studied groups. This is in contradiction to the results from the study of Coulam et al., who found an increase of these polymorphisms among the group with deep vein thrombosis when compared with women with recurrent miscarriages [21]. A possible explanation is the difference in the cohort 
of patients since their studied groups consisted of 550 women experiencing recurrent miscarriage compared with 43 individuals with a history of deep vein thrombosis. Our group of patients with vascular disoders was more heterogenous, which could be the reason for this finding. In the present study F II, PAI and MTHFR had uncertain predicitve value. F V Leiden remains the mutant allele with the biggest impact on inherited thrombophilia [22]. However, this is a single center study and more patients from different centers should be included.

Two patients from the VDs group and one from the RPL group were combined heterozygote carriers for $\mathrm{F} \mathrm{V}$ and $\mathrm{F}$ II variants. This combined genotype could be a higher risk factor for thromobotic accidents since such patients had thrombosis at a significantly younger age compared to other cases $[23,24]$. However, due to the restricted number of combined heterozygotes we cannot estimate if there is a correlation.

Additionaly, the role of the mutant alleles for PAI and MTHFR as isolated risk factors was analyzed. The percentage of isolated carriers of PAI mutant allele was higher in the RPL group $28(22.8 \%)$ people compared to $13(18.3 \%)$ in the VDs group. It was the opposite for the homozygotes only for the mutated MTHFR alleles - $11(7.9 \%)$ participants from the RPL group and $6(9.0 \%)$ the other group. However, after comparing the role of the isolated homozygous state for any of these two polymorphisms, the results were statistically nonsignificant (Chi-square, df 0.07019.1; $\mathrm{p}=0.7911$ ). This corresponds with findings from other studies, which exclude their isolated role as possible risk factors for vascular disorders or RPL [25, 26].

From the 15 heterozygotes for F V Leiden in the VDs group $3(20.0 \%)$ patients were isolated carriers of this variant, $8(53.3 \%)$ patients are heterozygotes for $\mathrm{F} \mathrm{V}$ and one additional factor (PAI or MTHFR), and there were 4 (26.7) patients, who were heterozygotes for all three polymorphisms. However, the sample size of participants with coexistence of different thrombophilic variants is too small to estimate the additive effect.

There were 11 herozygotes for F V in the RSA group and only one woman (9.1\%) showed no mutant alleles for the other factors. Five women $(45.5 \%)$ were heterozygotes for $\mathrm{F} \mathrm{V}$ and one additional factor (PAI or MTHFR). Two women (18.2\%) had a coexistence of heterozygosity for $\mathrm{F} V$ together with homozygous state for the mutant allele for both PAI and MTHFR. Three women were combined heterozygotes for F V, PAI and MTHFR variants. However, the number of miscarriages was not increased significantly and was to two abortions. A larger number of participants is needed to evaluate the cumulative effect of the thrombophilic variants.

We also compared the frequency distribution for F V, F II and MTHFR among our studied groups and the expected genotype frequencies. The allelic frequencies were obtained from gnom AD database, which includes 141456 unrelated individuals sequenced [27].

There was no data for F II for Bulgarians and information about the distrubution among Europeans (Nonfinnish) was used. There were no allelic frequencies for PAI listed in the database for different populations.

For $\mathrm{F} V$ the data showed an increase percentage of homozygotes and heterozygotes in both studied groups, as for F II - only in the VDs group. This confirms findings from previous studies, that $\mathrm{F} \mathrm{V}$ and F II could have potential impact on thrombotic accidents [28]. For the MTHFR there was no difference between the expected and calculated genotype frequencies in the studied population.

MTHFR may not be a risk factor for inherited thrombophilia and more studies are needed [29, 30]. Moreover, the American College of Medical Genetics and Genomics' states that MTHFR mutations should never be included in any thrombophilia panel [31].

There were no listed allele frequencies of PAI in the genomic databases and we were unable to calculate the genotype frequecies. That is why we cannot conclude if PAI is a risk factor for vascular disorders or RPL. In spite of that, in a study by Adler, G., et al. there was a statistically significant association between carrying $4 \mathrm{G}$ allele and RPL in Bulgarian women $(p=0.018)$ [32]. However, there is no guideline, suggesting to include PAI polymorphisms in the thrombophilia panel and more studies are needed to prove this finding in the Bulgarian population.

The patients included in the study were not tested for other thrombophilias such as antiphospholipid antibodies, protein $\mathrm{C}$ and $\mathrm{S}$ deficiency, etc., which could be considered as a possible limitation of the research. Further experiments are needed to evaluate the role of other thrombophilic risk factors.

Testing for thrombophilia has evolved rapidly from its beginning in the 1990s. Today, the benefits of this analysis are controversial and the recommendations state to do the test only in specific risk groups [33]. Despite of the limited impact that these analyses might have on the treatment process, clinicians often recommend testing for thrombophilia, including other factors with limited predictive value [34]. Nevertheless, F V Leiden remains the strongest factor for vascular disorders and RPL $[19,35]$. 


\section{CONCLUSION}

F V Leiden has a higher frequency among patients with vascular disorders compared to women with recurrent pregnancy loss and it could have an impact on the etiology of vascular diseases. Screening for variants, associated with inherited thrombophilia, especially for $\mathrm{F} V$, should be recommended to patients with thrombotic accidents since this mutation might be a significant risk factor. $\mathrm{F} V$ Leiden polymorphism has a higher frequency than the expected among women with primary infertility and recurrent miscarriages in the first trimester and should be offered as a screening test. The role of F II, PAI and MTHFR remains controversial.

Introducere. Scopul studiului a fost de a compara rolul variantelor genetice trombofilice în 2 grupe de paciente cu risc ridicat de afectare vasculară și avorturi spontane recurente.

Materiale si metode. Au fost incluse în studiu 200 de paciente dintre care 76 au avut accidente trombotice şi 124 au avut două sau mai multe avorturi spontane în primul trimestru. Acestea au fost testate pentru prezența factorului $V$ Leiden G1691A, factor II (F II) G20210A, inhibitorul activatorului de plasminogen (PAI) 4G/5G şi a polomorfismului C677T a MTHFR (metilentetrahidrofolat reductaza) prin Real-time PCR (RT-PCR) în cadrul Laboratorului de Genetică Medicală din Varna Bulgaria în perioada iunie 2016 și mai 2019. Au fost comparate frecvențele genotipurilor.

Rezultate. Pacienții cu istoric de accidente trombotice au avut o frecvență semnificativ statistic mai mare a F V Leiden comparativ cu pacientele care au avut avorturi spontane recurente. $N u$ au fost găsite alte diferențe semnificative pentru celelalte genotipuri studiate. Frecvența alelelor a fost calculată conform echilibrului Hardy-Weinberg. Procentul homozigoților pentru F V și F II a fost mai mare decât cel așteptat la cele două grupe de pacienți. Pentru MTHFR nu a fost înregistrată nicio diferență.

Concluzii. F V Leiden rămâne cel mai important factor de risc cardiovascular pentru afectare vasculară și risc de avort spontan recurent. Rolul F II, PAI și MTHFR rămâne controversat.

Correspondence to: Dr Mariya Levkova, Department of Medical Genetics, Medical University Varna, Marin Drinov Str 55,Varna, 9000, Bulgaria; tel. +359885692182;

E-mail: maria.levkova171@gmail.com

Conflict of interest disclosure: The authors declare that there are not conflicts of interest.

\section{REFERENCES}

1. LANE, D.A., P.M. MANNUCCI, K.A. BAUER, R.M. BERTINA, N.P. BOCHKOV, V. BOULYJNKOV, et al., Inherited thrombophilia: part 1. Thrombosis and haemostasis, 1996. 76(05): p. 651-662.

2. BUCHHOLZ, T. and C.J. THALER, Inherited thrombophilia: impact on human reproduction. American Journal of Reproductive Immunology, 2003. 50(1): p. 20-32.

3. CORIU, L., R. UNGUREANU, R. TALMACI, V. USCATESCU, M. CIRSTOIU, D. CORIU, et al., Hereditary Thrombophilia and thrombotic events in pregnancy: single-center experience. Journal of medicine and life, 2014. 7(4): p. 567.

4. BERTINA, R.M., B.P. KOELEMAN, T. KOSTER, F.R. ROSENDAAL, R.J. DIRVEN, H. DE RONDE, et al., Mutation in blood coagulation factor $V$ associated with resistance to activated protein C. Nature, 1994. 369(6475): p. 64.

5. RIDKER, P.M., J.P. MILETICH, C.H. HENNEKENS, and J.E. BURING, Ethnic distribution of factor $V$ Leiden in 4047 men and women: implications for venous thromboembolism screening. Jama, 1997. 277(16): p. 1305-1307.

6. POORT, S.R., F.R. ROSENDAAL, P.H. REITSMA, and R.M. BERTINA, A common genetic variation in the 3'-untranslated region of the prothrombin gene is associated with elevated plasma prothrombin levels and an increase in venous thrombosis. Blood, 1996. 88(10): p. 3698-3703.

7. ROSENDAAL, F., C.J.M. DOGGEN, A. ZIVELIN, V. ARRUDA, M. AIACH, D. SISCOVICK, et al., Geographic distribution of the $20210 \mathrm{G}$ to A prothrombin variant. Thrombosis and haemostasis, 1998. 79(04): p. 706-708.

8. BARCELLONA, D., L. FENU, C. CAULI, G. PISU, and F. MARONGIU, Allele 4G of gene PAI-1 associated with prothrombin mutation G20210A increases the risk for venous thrombosis. Thrombosis and haemostasis, 2003. 90(12): p. 1061-1064. 
9. WILLIAMS, K.T. and K.L. SCHALINSKE, Homocysteine metabolism and its relation to health and disease. Biofactors, 2010. 36(1): p. 19-24.

10. DEN HEIJER, M., S. LEWINGTON, and R. CLARKE, Homocysteine, MTHFR and risk of venous thrombosis: a meta-analysis of published epidemiological studies. Journal of Thrombosis and Haemostasis, 2005. 3(2): p. 292-299.

11. HICKS, L.K., H. BERING, K.R. CARSON, J. KLEINERMAN, V. KUKRETI, A. MA, et al., The ASH Choosing Wisely® campaign: five hematologic tests and treatments to question. Blood, 2013. 122(24): p. 3879-3883.

12. CONNORS, J.M., Thrombophilia testing and venous thrombosis. New England Journal of Medicine, 2017. 377(12): p. $1177-1187$.

13. SIMIONI, P., Who should be tested for thrombophilia? Current opinion in hematology, 2006. 13(5): p. 337-343.

14. ANTONOV, A., Correlation between Tumor Angiogenesis, Mutation Load, Changes in the Blood Count and the Thrombogenic Risk in Patients with Essential Thrombocythaemia and Polycythaemia Veral//Корелационна зависимост между туморната ангиогенеза, мутационния товар, промените в кръвната картина, и тромбогенния риск при пациенти с есенциална тромбоиитемия и полицитемия вера. 2018, Medical University of Varna.

15. NIKOLOVA-VLAHOVA M., SAVOV AL., BALEVA M. AND KARAGIOZOVA ZH., Hereditary thrombophilic factors and antiphospholipid syndrome. Medicinski pregled, 2019. 55(1): p. 46-52.

16. BENDER ATIK, R., O.B. CHRISTIANSEN, J. ELSON, A.M. KOLTE, S. LEWIS, S. MIDDELDORP, et al., ESHRE guideline: recurrent pregnancy loss. 2018, Oxford University Press DOI: 10.1093/hropen/hoy004.

17. IVANOV, P.D., R.S. KOMSA-PENKOVA, E.I. KONOVA, K.S. KOVACHEVA, M.N. SIMEONOVA, and J.D. POPOV, Association of inherited thrombophilia with embryonic and postembryonic recurrent pregnancy loss. Blood Coagulation \& Fibrinolysis, 2009. 20(2): p. 134-140.

18. GONÇALVES, R.O., L.R. FRAGA, W.V.B. SANTOS, A.F.L.D. CARVALHO, B.A.V. CERQUEIRA, M.A.C. SARNO, et al., Association between the thrombophilic polymorphisms MTHFR C677T, Factor V Leiden, and prothrombin G20210A and recurrent miscarriage in Brazilian women. 2016.

19. SERGI, C., T. AL JISHI, and M. WALKER, Factor V Leiden mutation in women with early recurrent pregnancy loss: a metaanalysis and systematic review of the causal association. Archives of gynecology and obstetrics, 2015. 291(3): p. 671-679.

20. WRAMSBY, M., M. STEN-LINDER, and K. BREMME, Primary habitual abortions are associated with high frequency of factor V Leiden mutation. Fertility and sterility, 2000. 74(5): p. 987-991.

21. COULAM, C.B., D. WALLIS, J. WEINSTEIN, D.S. DASGUPTA, and R.S. JEYENDRAN, Comparison of thrombophilic gene mutations among patients experiencing recurrent miscarriage and deep vein thrombosis. American Journal of Reproductive Immunology, 2008. 60(5): p. 426-431.

22. SIMONE, B., V. DE STEFANO, E. LEONCINI, J. ZACHO, I. MARTINELLI, J. EMMERICH, et al., Risk of venous thromboembolism associated with single and combined effects of Factor V Leiden, Prothrombin 20210A and Methylenetethraydrofolate reductase C677T: a meta-analysis involving over 11,000 cases and 21,000 controls. 2013, Springer.

23. SILAN, F., I. MOSSE, A. GONCHAR, N. SEDLYAR, A.V. KILCHEVSKY, O. YILDIZ, et al., Comparison of the thrombophilic gene polymorphisms and recurrent pregnancy loss: Results on combined gene effect of FV Leiden, FVR2, FXIII, MTHFR (A1298C and C677T), PAI-1 4G/5G and ACE I/D genes in RPL Women from Misk/Belarus and Canakkale-Sivas/Turkey. Biomedical Genetics and Genomics, 2016. 1(4): p. 87-93.

24. EMMERICH, J., F.R. ROSENDAAL, M. CATTANEO, M. MARGAGLIONE, V. DE STEFANO, T. CUMMING, et al., Combined effect of factor $V$ Leiden and prothrombin 20210A on the risk of venous thromboembolism. Thrombosis and haemostasis, 2001. 86(09): p. 809-816.

25. GOODMAN, C., J. HUR, C.S. GOODMAN, R.S. JEYENDRAN, and C. COULAM, Are polymorphisms in the ACE and PAI-1 genes associated with recurrent spontaneous miscarriages? American Journal of Reproductive Immunology, 2009. 62(6): p. 365-370.

26. SAHIN, U. and M. OZCAN, The End of a Long Debate: Methylenetetrahydrofolate Reductase Gene Polymorphisms do not Increase Thrombosis Risk. The Eurasian journal of medicine, 2017. 49(1): p. 76.

27. KARCZEWSKI, K.J., L.C. FRANCIOLI, G. TIAO, B.B. CUMMINGS, J. ALFÖLDI, Q. WANG, et al., Variation across 141,456 human exomes and genomes reveals the spectrum of loss-of-function intolerance across human protein-coding genes. BioRxiv, 2019: p. 531210.

28. ZARROUK, M., S. SALIM, J. ELF, A. GOTTSÄTER, and S. ACOSTA, Testing for thrombophilia in mesenteric venous thrombosis-Retrospective original study and systematic review. Best Practice \& Research Clinical Gastroenterology, 2017. 31(1): p. 39-48.

29. HWANG, K.R., Y.M. CHOI, J.J. KIM, S.K. LEE, K.M. YANG, E.C. PAIK, et al., Methylenetetrahydrofolate reductase polymorphisms and risk of recurrent pregnancy loss: A case-control study. Journal of Korean medical science, 2017. 32(12): p. $2029-2034$.

30. ELGARI, M.M., N.A. IBRAHIM, A.R.M. MUDDATHIR, F.M. ELTOOM, and I.M. IBRAHIM, Frequency of thrombophilic gene mutations in patients with deep vein thrombosis and in women with recurrent pregnancy loss. Open Life Sciences, 2017. 12(1): p. 162-166.

31. PETRILLI, C.M., L. HEIDEMANN, M. MACK, P. DURANCE, and V. CHOPRA, Inpatient inherited thrombophilia testing. 2016.

32. ADLER, G., E. MAHMUTBEGOVIC, A. VAlJEVAC, M.A. ADLER, N. MAHMUTBEGOVIC, K. SAFRANOW, et al., Association between-675 ID, 4G/5G PAI-1 gene polymorphism and pregnancy loss: A systematic review. Acta Informatica Medica, 2018. 26(3): p. 156.

33. MIDDELDORP, S., Inherited thrombophilia: a double-edged sword. ASH Education Program Book, 2016. 2016(1): p. 1-9.

34. KUDO, M., H.L. LEE, I.A. YANG, and P.J. MASEL, Utility of thrombophilia testing in patients with venous thrombo-embolism. Journal of thoracic disease, 2016. 8(12): p. 3697.

35. ZÖLLER, B., O. MELANDER, P.J. SVENSSON, and G. ENGSTRÖM, Factor V Leiden paradox in a middle-aged Swedish population: A prospective study. Vascular Medicine, 2018. 23(1): p. 52-59.

Received $31^{\text {st }}$ July 2019 